\title{
はんだのクリープ特性に及ぼす微視組織と寸法の影響*
}

\author{
頝 纈 英 之*1, 高 橋 恭 平*1 \\ 小川武 史*2, 大澤直 ${ }^{* 3}$
}

\section{Influences of Microstructure and Specimen Size on Creep Properties of Solders}

\author{
Hideyuki KOHKETSU, Kyouhei TAKAHASHI, \\ Takeshi OGAWA*4 and Tadashi OHSAWA \\ ${ }^{* 4}$ Department of Mechanical Engineering, Aoyama Gakuin University, \\ 5-10-1 Fuchinobe, Sagamihara-shi, Kanagawa, 229-8558 Japan
}

\begin{abstract}
The influences of microstructure and specimen size on creep properties of $\mathrm{Sn}-37 \mathrm{~Pb}$ and $\mathrm{Sn}-3.5$ $\mathrm{Ag}$ solders were investigated by nano-indentation tests and tensile creep tests for fine wire solders. The nano-indentation tests enabled us to measure the indentation creep properties of the specific microstructures individually. Tensile creep experiments were performed on our original creep testing machine for fine wire solders with the diameters of $0.2,0.5$ and $1.0 \mathrm{~mm}$. For the $\mathrm{Sn}-37 \mathrm{~Pb}$ solder, the creep deformation properties were uniform for both $\alpha$ and $\beta$ phases and grain boundary sliding was the dominating creep mechanism. For the $\mathrm{Sn}-3.5 \mathrm{Ag}$ solder, creep deformations of $\alpha$ phase were observed under much smaller stress levels than those for $\varepsilon$ phase, and thus the creep deformations occurred only in $\alpha$ phase, which resulted in the nucleation of microvoids around the $\varepsilon$ phase. The tensile creep tests for wire solders revealed that the significance of specimen size on the creep properties is strongly influenced by the microstructure of the solders.
\end{abstract}

Key Words : Creep, Size Effect, Material Testing, Nano-indentation, Solder

\section{1. 緒言}

最近の電子機器の小型軽量化・高密度化に伴い, 電子回路基板の接合部は極めて小さくなり，かつ過酷 な熱環境にさらされている.これに用いられるはんだ は，環境問題への配慮から鉛フリー化が進められてお り，多くの鉛フリーはんだが実用化に向けて開発され ている. 低融点のはんだ接合部では, 実働状態で再結 晶温度を超えており, クリープ損傷や微視組織変化が 常に発生している. したがって, 機器の健全性評価の ためには, はんだのクリープ特性を微視組織との関連 のもとに明らかにしておくことが重要である. 著者ら は, はんだの力学特性をインデンテーション法によっ て予測する方法を確立した ${ }^{(1)(2)}$. この手法をナノイン デンテーション試験（圧子の押込み深さ $h$ が数百 $\mathrm{nm}$ 以下）に拡張すれば, 微視組織の各相に関してクリー プ特性を含む力学特性が予測でき，はんだ接合部の詳 細な微視組織的評価が可能になると期待される.

* 原稿受付 2005 年 2 月 23 日.

*1 学生員, 青山学院大学大学院理工学研究科(画 229-8558 相 模原市淵野辺 5-10-1).

*2 正員, 青山学院大学理工学部.

$* 3$ 青山学院大学理工学部.

E-mail : ogawa@cc.aoyama.ac.jp
一般に，はんだのクリープ特性は，直径 $10 \mathrm{~mm}$ 程 度の丸棒標準試験片を用いて測定されている(3). 一方, はんだ接合部は $100 \mu \mathrm{m}$ 以下の微細なものが広く使わ れるようになった. 高温にさらされた微視組織は粗大 化する傾向にあるので, 微視組織の代表寸法がはんだ 接合部の大きさ程度になることも考えられる. したが って, 直径の大きなバルク試験片で測定したクリープ 特性と微細なはんだ接合部のクリープ特性は異なるこ とが懸念され, クリープ特性の寸法効果を明らかにし

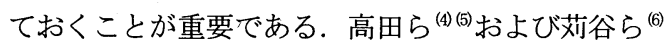
は，はんだのクリープ特性に及ぼす寸法効果を明らか にした.これらの研究では, ミニチュアサイズの丸棒 試験片を機械加工によって製作しているが，このよう な加工はきわめて困難である. また, 微視組織との関 連がきわめて重要であるが，十分な検討はなされてい ない(6).

そこで本研究では，Sn-37Pb はんだに加えて代表的 な鉛フリーはんだである $\mathrm{Sn}-3.5 \mathrm{Ag}$ はんだについて, ナ ノインデンテーション試験をはんだの微視組織解析に 適用するとともに, 市販の細線はんだを試験片とした クリーブ試験機の開発を行った. 得られた結果をもと 
Tablel Chemical compositions of solders (mass, \%).

\begin{tabular}{ccccccccccccc}
\hline Solder material & $\mathrm{Pb}$ & $\mathrm{Ag}$ & $\mathrm{Sb}$ & $\mathrm{Cu}$ & $\mathrm{Bi}$ & $\mathrm{Zn}$ & $\mathrm{Fe}$ & $\mathrm{Al}$ & $\mathrm{As}$ & $\mathrm{Cd}$ & $\mathrm{In}$ & $\mathrm{Sn}$ \\
\hline $\mathrm{Sn}-37 \mathrm{~Pb}$ (cast) & 37.24 & - & 0.002 & - & - & 0.0001 & 0.002 & - & - & - & - & Bal. \\
$\mathrm{Sn}-3.5 \mathrm{Ag}$ (cast) & - & 3.46 & - & - & - & 0.0001 & 0.002 & - & - & - & - & Bal. \\
$\mathrm{Sn}-37 \mathrm{~Pb}$ (wire) & 37.13 & - & 0.075 & - & 0.01 & 0.0003 & 0.003 & - & - & - & - & Bal. \\
$\mathrm{Sn}-3.5 \mathrm{Ag}$ (wire) & 0.01 & 3.54 & 0.015 & - & 0.01 & 0.0001 & 0.002 & - & - & - & - & Bal. \\
$\mathrm{Sn}-37 \mathrm{~Pb}$ (wire, $\phi=0.2 \mathrm{~mm})$ & 36.4 & 0.005 & 0.01 & 0.001 & 0.02 & 0.01 & 0.006 & 0.005 & 0.02 & 0.001 & 0.01 & Bal. \\
\hline
\end{tabular}

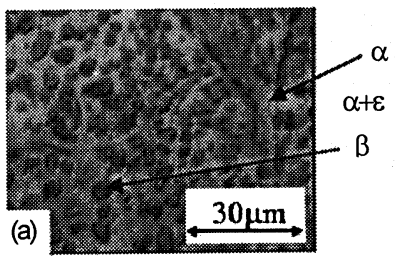

Fig. 1 Microstructures of cast solders of $\mathrm{Sn}-37 \mathrm{~Pb}$ (a) and Sn-3.5Ag (b).

に，はんだのクリープ特性に及ぼす微視組織と寸法の 影響を明らかにした。

\section{2. 微視的なクリープ特性}

\section{1 材料および実験方法＼cjkstart供試材は，二ホン八} ンダ（株）の $\mathrm{Sn}-37 \mathrm{~Pb}$ および $\mathrm{Sn}-3.5 \mathrm{Ag}$ 鋳造材であり， 化学成分を表 1 に示す. それぞれ $556 \mathrm{~K}$ および $594 \mathrm{~K}$ の溶融したはんだを室温の軟鋼鋳型に流し込み, 直径 $15 \mathrm{~mm}$, 長さ $200 \mathrm{~mm}$ の円柱状の素材を作製した. こ の素材を旋盤で直径 $10 \mathrm{~mm}$ に機械加工した後, 約 10 $\mathrm{mm}$ の長さに切断し, 組織安定化のために融点の $87 \pm$ $1 \%$ の温度（Sn-37Pbは $398 \mathrm{~K}, \mathrm{Sn}-3.5 \mathrm{Ag}$ は $433 \mathrm{~K}$ ) で 1 時間の熱処理を施した ${ }^{(3)}$. 断面にエメリー紙（〜 \#2000）研磨およびバフ研磨を施した後, 電解研磨に よって仕上げた. 電解研磨は $273 \mathrm{~K}$ の過塩素酸 $8 \%$, ブトキシエタノール $10 \%$, エタノール $70 \%$, 蒸留水 $12 \%$ 加成る溶夜を用い, 電圧 $20 \sim 25 \mathrm{~V}$, 研磨時間 5 秒の条件で行った. 電解研磨面を光学顕微鏡で観察す ると図 1 のような微視組織が観察された. Sn-37Pb は 白い $\alpha$ 相 $(\mathrm{Sn}$ rich) と黒い $\beta$ 相 $(\mathrm{Pb}$ rich)の共晶組織である. Sn-3.5Agには，白い $\alpha$ 相(Sn rich)と黒い金属間化合物の $\varepsilon$ 相 $\left(\mathrm{Ag}_{3} \mathrm{Sn}\right)$ を多く含む $(\alpha+\varepsilon)$ 相が認められる.

インデンテーション試験には, ナノスコピック表 面検査装置（島津製作所侏，SPH-1）を用い，対稜角 $115^{\circ}$ の Berkovich圧子の試験力 $F$ と押込み深さ $h$ の関係 を測定した. Sn-37Pb および Sn-3.5Ag の負荷および除 荷速度 $\mathrm{d} F / \mathrm{d} t$ は, それぞれ 12.5 および $25 \mu \mathrm{N} / \mathrm{s}$ とし, 最 大の試験力 $F=500(\mathrm{Sn}-37 \mathrm{~Pb})$ およよび $1000 \mu \mathrm{N}(\mathrm{Sn}-3.5 \mathrm{Ag})$ を $120 \mathrm{~s}$ 保持した. 図 2 にSPH-1 の AFM機能によって観 察された組織写真と圧痕の例を示す. 微視組織の寸法

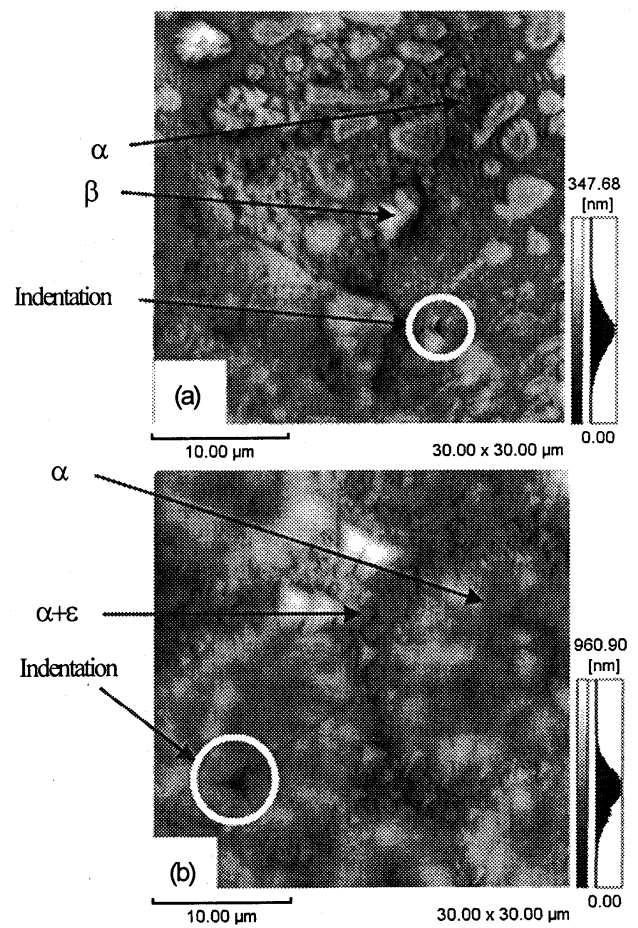

Fig. 2 AFM image of indentation on the specific microstructures for $\mathrm{Sn}-37 \mathrm{~Pb}$ (a) and $\mathrm{Sn}-3.5 \mathrm{Ag}$ (b).

と比較して, 圧痕寸法は小さく, 微視組織の構成相ご とに力学特性の評価が可能である.

2.2 実験結果 室温におけるインデンテーショ ン試験で得られた $F-h$ 曲線を図 3 に示寸. $\mathrm{Sn}-37 \mathrm{~Pb}$ の 場合， $\alpha$ 相と $\beta$ 相に対して試験を行った. 両者の $F-h$ 曲線に顕著な差異は認められない: 一方, Sn-3.5Ag の 場合, $\alpha$ 相と $(\alpha+\varepsilon)$ 相の $F-h$ 曲線には顕著な差異が認 められる. はんだは室温でクリープ変形を示すことか ら, $F$ を一定とした保持過程で $h$ が増大する. 保持過 程における $h$ の変化からクリープ特性を求めた ${ }^{(1)(2)}$. 一方, 負荷過程においてもクリープ変形は生じている が，その影響は小さいと考えて，負荷過程終了直後の $h$ からビッカース硬さ $H V$ を求めた. 得られた $H V$ と クリープ特性を図 4 および図 5 に示す. 図には $F=2 \mathrm{~N}$ のインデンテーション試験で求められた $H V$ およびク 

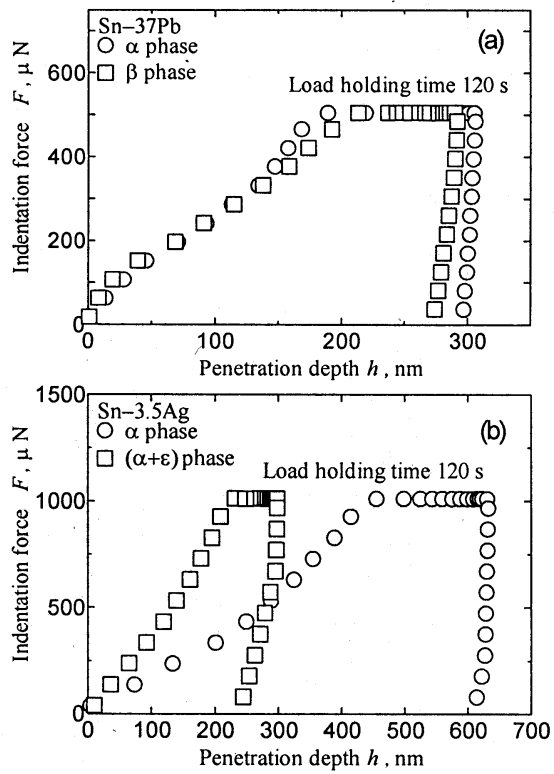

Fig. $3 F-h$ curves of $\mathrm{Sn}-37 \mathrm{~Pb}$ (a) and $\mathrm{Sn}-3.5 \mathrm{Ag}$ (b)

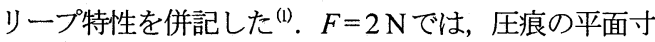
法が数 $100 \mu \mathrm{m}$ となるので，それぞれのはんだのバル ク特性が得られている. Sn- $37 \mathrm{~Pb}$ の場合， $\alpha$ 相と $\beta$ 相の $H V$ およびクリープ特性はバルク特性とほぼ一致して いる. 一方, Sn-3.5Ag の場合， $\alpha$ 相はバルク特性より も軟質, $(\alpha+\varepsilon)$ 相は硬質の挙動を示している.

\section{3. 細線のクリープ特性}

\section{1 材料および実験方法 供試材の細線はんだ}

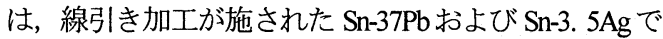
あり，直径 $0.2 ， 0.5$ および $1.0 \mathrm{~mm}$ であり，化学成分を 表 1 に示す. Sn-37Pb の直径 $0.2 \mathrm{~mm}$ は田中電子工業 （株），その他はニホンハンダ（株）製である. Sn$37 \mathrm{~Pb}$ の顕微鏡組織を図 6(a)および(b)に示す. 線引き加 工の影響により，図 1 に示した鋳造材とはまったく異 なる微視組織の様相となっている. 組織安定化のため に, $398 \mathrm{~K}$ で熱処理を施すと, 粗粒化の傾向が認めら れる. 直径が 0.5 おび $1.0 \mathrm{~mm}$ の試料については $48 \mathrm{~h}$, 直径 $0.2 \mathrm{~mm}$ の試料については $1 \mathrm{~h}$ の熱処理で図 6 (b) と ほぼ同様な組織様相になったので，これらを線引き加 工の影響がほぼ除外された組織状態と考えた．図 6 (c) および(d)に示す Sn-3.5Ag の顕微鏡組織も鋳造材とは 異なっており，図 1(b)の $\alpha$ 相が認められず，全体が $(\alpha+\varepsilon)$ 相の共晶組織の様相を呈していた. $433 \mathrm{~K}$ で熱処 理を施しても顕微鏡組織の顕著な変化は認められなか ったが，1 h および $48 \mathrm{~h}$ の熱処理を施した試験片をク リープ試験に供した。

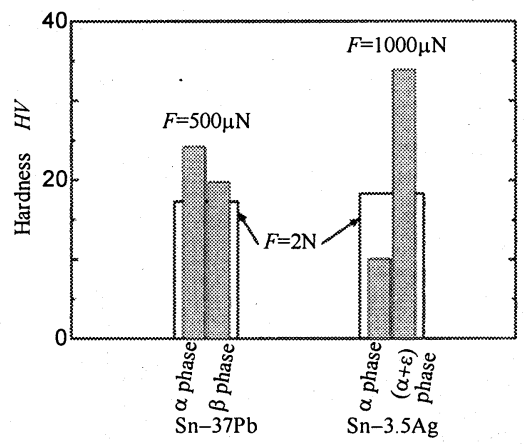

Fig. 4 Comparison of Vickers hardness obtained by micro-indentation and nano-indentation.
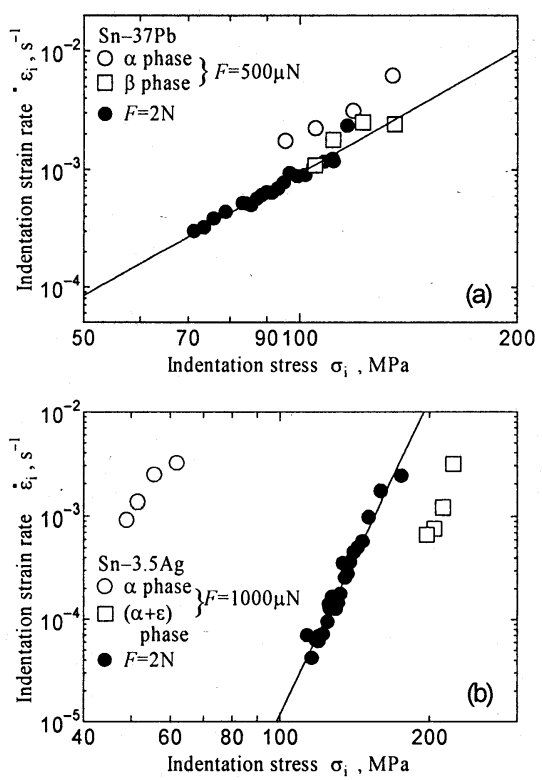

Fig. 5 Indentation creep characteristics of $\mathrm{Sn}-37 \mathrm{~Pb}$ (a) and $\mathrm{Sn}-3.5 \mathrm{Ag}$ (b).
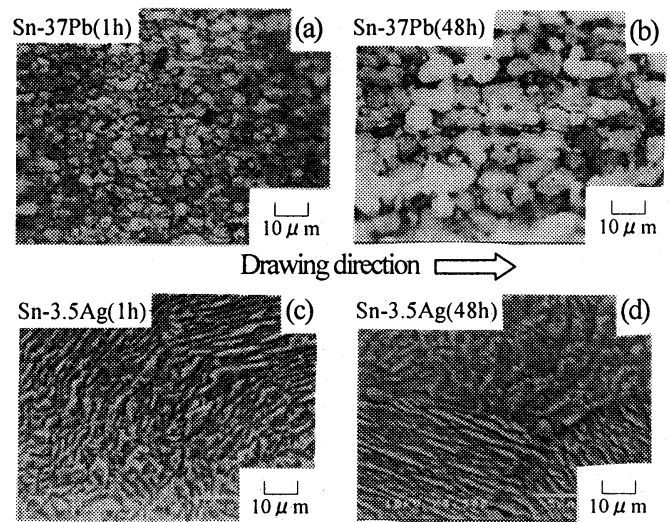

Fig. 6 Microstructures of wire solders of $\mathrm{Sn}-37 \mathrm{~Pb}(\mathrm{a})$ (b) and $\mathrm{Sn}-3.5 \mathrm{Ag}$ (c) (d), heat treated for $1 \mathrm{~h}$ (a) (c) or $48 \mathrm{~h}$ (b) (d). 


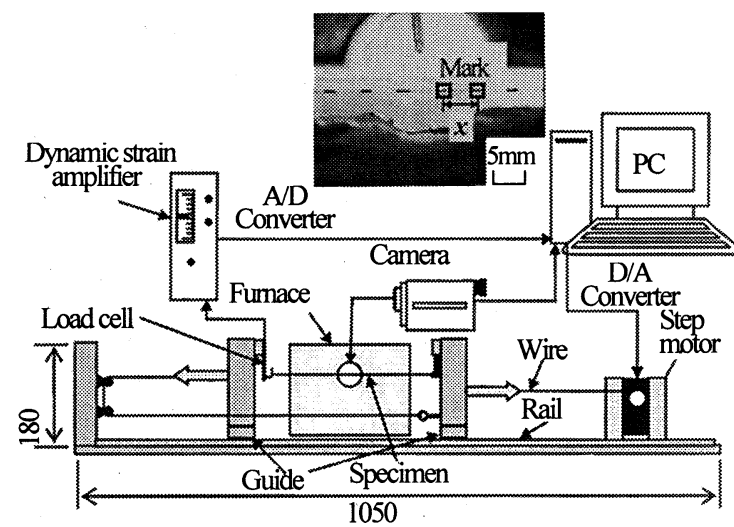

Fig. 7 Creep testing machine for fine wire solders.

細線のクリープ試験は, 図 7 に示す自作の引張試 験機によって行った. 試験片である細線はんだは，リ ニアガイドの上に設置した可動支柱の間に取り付けら れている，その一端は容量 $20 \mathrm{~N}$ の自作ロードセルに 固定し, 他端はステップモータで変位を与える可動支 柱に固定されている. 両端の可動支柱は固定支柱のプ ーリーを介してスチールワイヤーでつながれており， 互いに逆方向へ同じ変位量が発生する機構となってい る. ロードセルの出力は $\mathrm{A} / \mathrm{D}$ コンバータを介して PC に送られ，ステップキータの駆動にフィードバックさ れている. 試験条件は試験力 $P$ 制御であり,$P$ 一定の 保持過程において $5 \%$ 以下の誤差で制御が行われてい る. 可動支柱の間には電気炉を設置し, 試験片中央部 の $50 \mathrm{~mm}$ の範囲が一定温度となっていることを確認 した．試験片の変形は，試験片にインクで付けた約 $5 \mathrm{~mm}$ 間隔のマーク画像を, 電気炉の観察空からビデ オカメラで $\mathrm{PC}$ に取り込み，同一点探索法に基づく自 作の画像伸び計で測定した. 同一点探索にはサブピク セル処理を組み込んでおり，測定の分解能は約 $5 \mu \mathrm{m}$ 程度である. 試験温度は $313 \mathrm{~K}$ とした. なお, 室温で 実験を行うと，両端の試験片固定部から破断する.

3.2 実験結果 クリーブ試験で得られた公称応 力 $\sigma_{n}$ と公称ひずみ白の関係から求めた真ひずみにおよ びその傾きから求めた真ひずみ速度 $\dot{\varepsilon}$ と時間 $t$ の関係

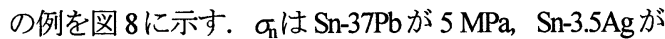
$12 \mathrm{MPa}$ である. 両者の破断延性は大きく異なるが， いずれの場合にも 1 次クリープはほとんど認められず, 2 次クリープと 3 次クリープの挙動が観察される. Sn$37 \mathrm{~Pb}$ の 3 次クリープの挙動は, クリープひずみの増 大に伴う断面減少により, 真応力のが増大することに 起因している. 他の試験片や応力条件に対する実験に おいても，同様な傾向が得られた．破断延性を表 2 に 示す. Sn-37Pb の場合にはの而が高いほど破断延性が小
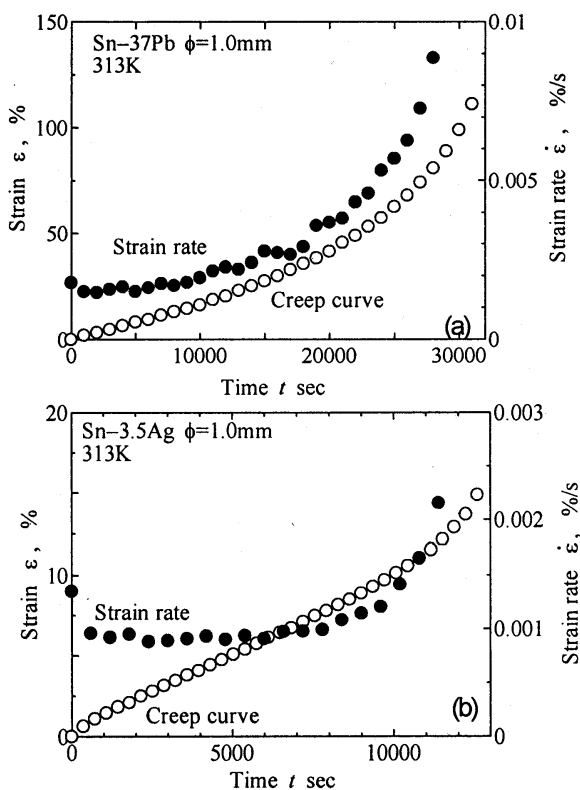

Fig. 8 Creep curves and the derived creep strain rate for $\mathrm{Sn}^{-}$ $37 \mathrm{~Pb}$ (a) and $\mathrm{Sn}-3.5 \mathrm{Ag}$ (b).

Table2 Creep test conditions and elongations.

\begin{tabular}{|c|c|c|c|c|c|}
\hline \multirow{2}{*}{ Solders } & \multirow{2}{*}{$\begin{array}{l}\text { Aging } \\
\text { time }\end{array}$} & \multirow{2}{*}{$\begin{array}{l}\text { Stress } \\
\mathrm{MPa}\end{array}$} & \multicolumn{3}{|c|}{ Elongation \% } \\
\hline & & & $0.2 \mathrm{~mm} \mathrm{dia}$ & $.5 \mathrm{~mm} \mathrm{di}$ & $.0 \mathrm{~mm}$ dia. \\
\hline \multirow[t]{9}{*}{$\mathrm{Sn}-37 \mathrm{~Pb}$} & $1 \mathrm{~h}$ & 5 & 73.2 & 123.4 & 112.7 \\
\hline & & 7 & 60.15 & 114.2 & 98.8 \\
\hline & & 10 & 48.33 & 110.6 & 68.4 \\
\hline & $10 \mathrm{~h}$ & 5 & - & 95.9 & 110.6 \\
\hline & & 7 & - & 96 & 88.4 \\
\hline & & 10 & - & 79.1 & 89.3 \\
\hline & $48 \mathrm{~h}$ & 5 & - & 111.8 & 111.2 \\
\hline & & 7 & - & 100.9 & 93.2 \\
\hline & & 10 & - & 88.8 & 66 \\
\hline \multirow[t]{10}{*}{ Sn-3.5Ag } & $\mathrm{lh}$ & 12 & - & - & 7.92 \\
\hline & & 14 & - & 4.98 & 9.58 \\
\hline & & 15 & - & 5.83 & 13.03 \\
\hline & & 16 & - & 8.19 & \\
\hline & $48 \mathrm{~h}$ & 12 & - & - & 14.86 \\
\hline & & 13 & - & 7.5 & - \\
\hline & & 14 & - & 5.5 & 15.68 \\
\hline & & 15 & - & 9.32 & 10.29 \\
\hline & & 16 & - & 9.34 & - \\
\hline & & 18 & - & 14.65 & - \\
\hline
\end{tabular}

さくなる傾向が見られるが，Sn-3.5Ag では一貫した傾 向は見られない。

図 8 のクリープ試験から $\dot{\varepsilon}$ の最小值を求め, $\sigma_{\mathrm{n}}$ と の関係をバルク試験片の結果と比較して図 9〜11 に示 す. なお, Sn-37Pb のバルク試験片の試験温度は細線 はんだよりも $10 \mathrm{~K}$ 高い. いずれの場合にも，次式で 示されるノートン則が成立している.

$$
\dot{\varepsilon}=A \sigma_{\mathrm{n}}{ }^{n}
$$

ここで, $A$ はクリープ定数, $n$ は応力指数である. 図 9 および図 10 は，それぞれ Sn-37Pbおよび Sn-3.5Ag の 

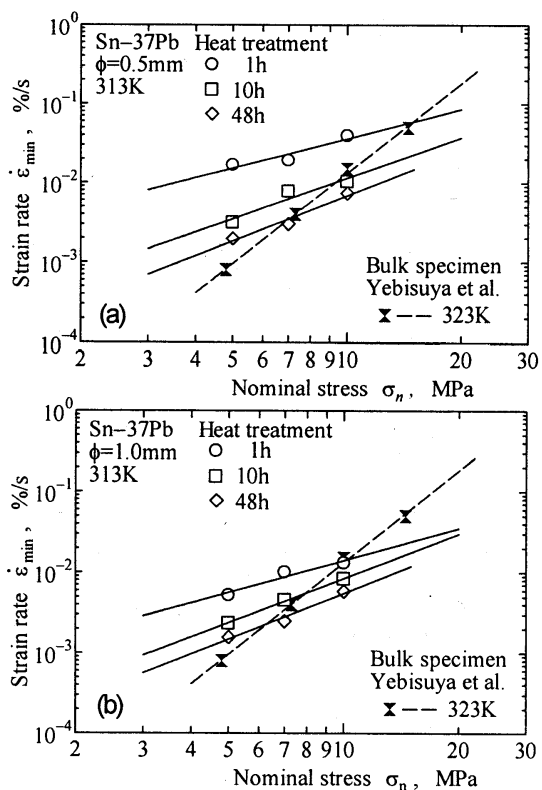

Fig. 9 Dependence of annealing time on creep characteristics of $\mathrm{Sn}-37 \mathrm{~Pb}$ solder with diameters of $0.5 \mathrm{~mm}$ (a) and $1.0 \mathrm{~mm}$ (b).

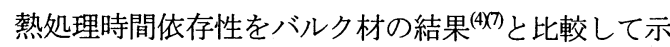
している. 図(a)は直径 $0.5 \mathrm{~mm}$, 図(b)は直径 $1.0 \mathrm{~mm}$ の 結果である. Sn-37Pb の場合, 熱処理時間の増加に伴

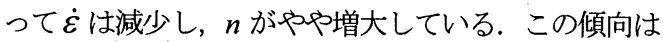
線引き加工の程度が大きい直径 $0.5 \mathrm{~mm}$ において顕著 である. 一方, Sn-3.5Ag の場合, 熱処理時間の増加に

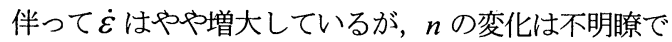
ある.

線引き加工の影響が最も小さい $48 \mathrm{~h}$ の熱処理を行 つた試験片について，試験片直径依存性を図 11 に示 す. Sn-37Pb の場合，寸法効果はほとんど認められず, 細線はんだとバルク試験片の結果は近い值を示してい るが，細線はんだの $n$ 值は小さい，一方， $\mathrm{Sn}-3.5 \mathrm{Ag}$ の 場合, バルク試験片よりも細線はんだの $\dot{\varepsilon}$ はかなり大 きく, $n$ も大きい. このように，両細線はんだの寸法 依存性は明らかに異なっている。

クリープ破断した試験片側面の走査型電子顕微鏡 写真を図 12 に示す。これらは熱処理を $48 \mathrm{~h}$ 施した直 径 $0.5 \mathrm{~mm}$ の細線はんだの結果であり， $\sigma_{\mathrm{n}}$ は $\mathrm{Sn}-37 \mathrm{~Pb}$ が $10 \mathrm{MPa}, \mathrm{Sn}-3.5 \mathrm{Ag}$ が $18 \mathrm{MPa}$ である. Sn-37Pbには粒界 き裂が多く認められるのに対して, Sn-3.5Ag は粒内に 空孔が発生している.

\section{4. 考察}

微視的なクリープ特性の検討から, Sn-37Pb および Sn-3.5Ag はんだのクリープ変形機構は，かなり異なる.
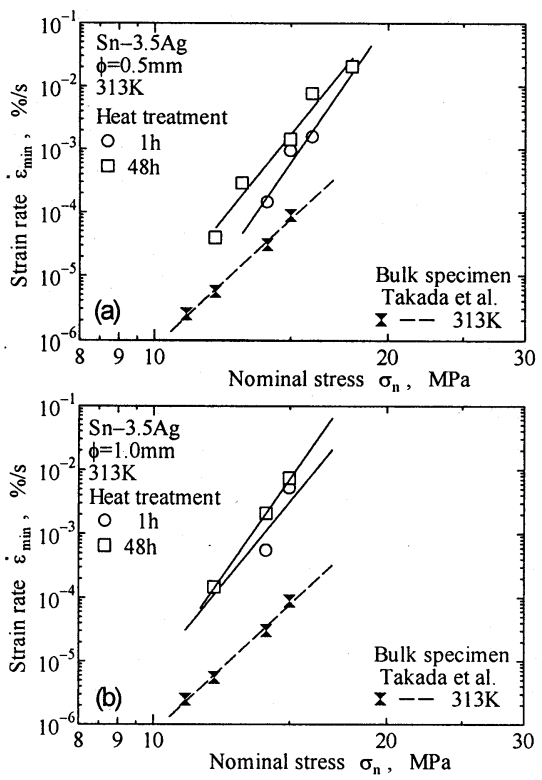

Fig. 10 Dependence of annealing time on creep characteristics of $\mathrm{Sn}-3.5 \mathrm{Ag}$ solder with the diameters of $0.5 \mathrm{~mm}$ (a) and $1.0 \mathrm{~mm}$ (b).
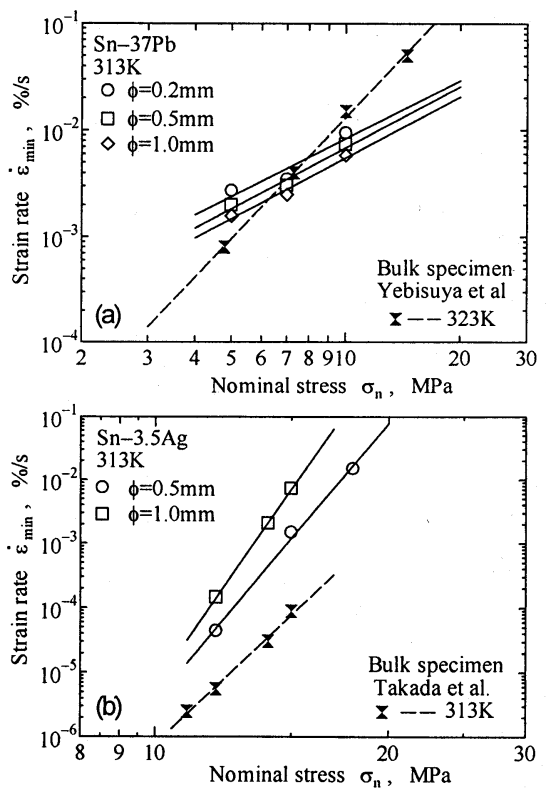

Fig. 11 Creep characteristics of fine wire solders of $\mathrm{Sn}-37 \mathrm{~Pb}$ (a) and $\mathrm{Sn}-3.5 \mathrm{Ag}$ (b).

$\mathrm{Sn}-37 \mathrm{~Pb}$ の場合， $\alpha$ 相と $\beta$ 相のクリープ特性に顕著な相 違はなく, バルク材の特性ともほぼ一致している.し たがって, クリープ変形は両相ともに発生していると 考えられる. これに対して Sn-3.5Ag の場合， $\alpha$ 相のク リープ変形は $\varepsilon$ 相 $\left(\mathrm{Sn}_{3} \mathrm{Ag}\right)$ を多く含んでいる $(\alpha+\varepsilon)$ 相より も低応力側で生じている. したがって，クリープ変形 


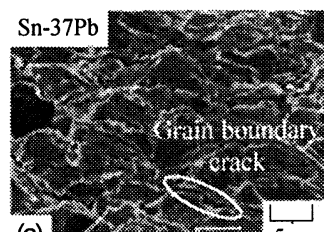

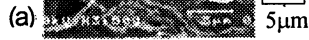

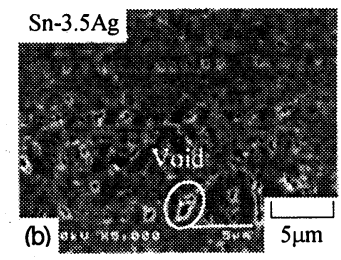

Fig. 12 SEM micrographs of creep fractured specimen surface of $\mathrm{Sn}-37 \mathrm{~Pb}$ (a) and $\mathrm{Sn}-3.5 \mathrm{Ag}$ (b).

は $\alpha$ 相のみで生じ, クリープ変形しない $\varepsilon$ 相が変形抵抗 として働き, 結果的にバルク材のクリープ変形特性が 得られるものである.

細線はんだの顕微鏡組織（図 6）は, 鋳造材の顕微 鏡組織（図 1）とかなり異なるが，含んでいる各相に 差異はなく, 上述の微視的な変形機構は同様であると 考えられる. この結果として, 図 8 のクリープ変形挙 動および図 12 のクリープ変形後の試験片様相が観察 されたものである.Sn-37Pb の場合，100\%を超えるク リープ変形が粒界すべりによって生じたと考えられ, 破断試験片の表面には粒界き裂が観察される。一方, $\mathrm{Sn}-3.5 \mathrm{Ag}$ の場合, クリープ変形しないE相 $\left(\mathrm{Sn}_{3} \mathrm{Ag}\right)$ のま わりの 相に微小空洞が発生することによってクリー プ損傷が累積され， $\varepsilon=10 \sim 20 \%$ でクリープ破断に至 った. 図 8(b)の $\dot{\varepsilon}$ が破断直前に増大寸るのは, 微小空 洞の発生と合体に起因するものである.

$\mathrm{Sn}-37 \mathrm{~Pb}$ の場合, 細線のクリープ特性がバルク材と 異なる原因は, 線引き加工および寸法の影響である.

図 9 および図 10 に示したように, 前者はクリープひ ずみ速度の加速とクリープ指数の低下をもたらした.

これらの挙動は, 融点の $87 \%$ の絶対温度で熱処理を 行うと消失する傾向を示した. この熱処理を $48 \mathrm{~h}$ 保 持することによって線引き加工の影響がほほ除外され るとすると, 図 11(a)に示したように寸法効果はほと んど認められなくなった. ただし，この熱処理状態に おいても， Sn-37Pb の細線はんだはクリープ指数がバ ルク材の結果よりも小さい.

Sn-3.5Ag の場合, 細線のクリープひずみ速度はバル ク材よりもかなり加速されていたが，線引き加工の顕 著な直径 $0.5 \mathrm{~mm}$ のクリープひずみ速度が直径 $1.0 \mathrm{~mm}$ の結果よりもやや低い. 図 11(b)からわかるように, これらの傾向は上記の熱処理を行ってもほとんど除去 できていない．この原因が寸法効果によるものか線引 き加工によるものかは明らかでない.

以上の考察から, 本研究で試験した Sn-37Pbおよび Sn-3.5Ag はんだのクリープ特性に及ぼす寸法の影響は, 細線はんだの製造過程で用いられる線引き加工に顕著 な影響を受けるが, その寄与はそれぞれのはんだの微
視組織状態とクリープ機構に強く依存している．実用 的に重要な加工の影響を受けない細線はんだのクリー プ特性は, 本研究の方法では評価ができなかった，し かし, 実機の電子回路接合部は, 繰返し熱忘力が負荷 されることによって漸次経時変化し，接合時の組織状 態が そのまま維持されとは考えられない.すなおち， 実用的な観点からは，実機の電子回路接合部の断面に おいてインデンテーション法による測定を行うことが 有効であると考えられる.

\section{5. 結言}

本研究では, Sn-37Pb および Sn-3.5Ag はんだについ て,ナノインデンテーション試験をはんだの微視組織 解析に適用するとともに, 市販の細線はんだを試験片 としたクリープ試験機の開発を行い，はんだのクリー プ特性に及ぼす微視組織と寸法の影響を明らかにした。 得られた主な結果は以下のとおりである.

(1) Sn-37Pb はんだの場合, $\alpha$ 相と $\beta$ 相のクリープ変 形特性の差異は小さく, 粒界すべりが支配機構である. Sn-3.5Ag はんだの場合, $\alpha$ 相のクリープ変形は $(\alpha+\varepsilon)$ 相 よりもかなり低応力側で発生したので, クリープ変形 は $\alpha$ 相のみで生じ， $\varepsilon$ 相のまわりの $\alpha$ 相に空孔が発生・ 成長・合体してクリープ破壊に至る.

（2）細線はんだのクリープ特性は，線引き加工に よる繊維状組織の影響を受ける. 加工の影響が顕著な ほど，クリープひずみ速度は Sn-37Pb で加速, Sn$3.5 \mathrm{Ag}$ で減速する傾向を示した.

(3) クリープ特性に及ぼす寸法の影響は，はんだ の種類と微視組織によって異なる.

本研究の一部は, 文部科学省 21 世紀 COE プログラ ムの一環として行われた。 記して謝意を表する.

\section{文献}

（1）宮本 輝・小川武史・大澤 直，材料； $51-4,445-$ 450 (2002).

（2）小山直哉・宮本輝 - 小川武史 - 大澤 直, 材料 試験技術，47-4，216-223(2002).

(3) はんだのクリープ試験法標準, 日本材料学会, JSMS-SD-8-04, 1-23 (2004).

(4) 高田晄男·坂根政男, 舞鶴高専紀要, 35, 1-5 (2000).

(5) 高田晄男 - 壇上博史 - 坂根政男 - 塚田 裕 - 西村 秀夫, 機論 A 編，69-683，1082-1087(2003).

（6）荻谷義治·浅井強·須賀唯知・大塚正久, Symp. Microjoining Assem. Tech. Electron, 10, 61-64 (2004).

（7）戎谷隆, 川久保隆，日本金属学会誌，57-4, 455-462 (1993). 